\title{
The Delinquency Evolution in Brazil and the Legal System Actions
}

\author{
Francisca Morais da Silveira ${ }^{1}$, Francisco de Jesus Silva de Sousa ${ }^{2}$, Daniel Aguiar Pereira \\ Filho $^{3}$, Elias Miguel Fernandes Nunes ${ }^{4}$, Vinícius Barros Costa Macedo ${ }^{5}$, Gustavo Adolfo \\ Siqueira Rocha ${ }^{6}$
}

\author{
${ }^{1}$ Teacher Law and Psychology Departament - Universidade Federal do Maranhão \\ 2Teacher Psychology Departament - Universidade Federal do Maranhão \\ ${ }^{3,4,5,6}$ Law Departament - Universidade Federal do Maranhão
}

Received: 10 Oct 2021; Received in revised form: 13 Nov 2021; Accepted: 20 Nov 2021; Available online: 30 Nov 2021

(C)2021 The Author(s). Published by Infogain Publication. This is an open access article under the CC BY license

(https://creativecommons.org/licenses/by/4.0/).

\begin{abstract}
Analysis of delinquency in Brazil and the characteristics of its evolution, bringing as focus its legal system. It aims to analyze crime in Brazil from the legal psychology perspective; study the origins of the practice of crimes in the country; analyze impunity and its relationship with the criminal practice; investigate the effectiveness of contemporaneous crime containment policies in Brazil. The research type is bibliographical, and the source of the data and statements used are found in articles found at the internet, concerning Legal Psychology, criminal statistics, criminology and contemporary crime containment policies. It found the existence of a gradual complexity of approaches to delinquency and the relationship that the penal and judicial system has in the perpetuation of disorders, due to an unevenness between the Brazilian reality and legal practice. It concludes that the criminal practice in Brazil is composed of several aspects, as long as social factors connected to the individual formation to deficient characteristics that the justice system presents and that contribute to the abidance of the crimes.
\end{abstract}

Keywords—delinquency, juridical system, Juridical Psychology, Brazil.

\section{INTRODUCTION}

Criminality in Brazil is a wound that has worsened on a daily basis and that directly influences the reduction in overall life quality of the population, imprisoned in their homes by an insecurity feeling. Furthermore, this social problem reaps the lives of thousands of young people, mostly blacks, who live in regions where the State - in charge of repairing social inequalities — is ineffective and opportunities for social ascension do not penetrate into their perspectives.

Regarding this, according to the Brazilian Applied Economic Research Institute (IPEA), the homicide rate for every 100,000 (one hundred thousand) inhabitants in 2017 was the highest in the entire country's history since 1980 (CERQUEIRA; BUENO, 2020). This fact is incontrovertible and shows the recrudescence of criminal practices in Brazilian territory. Therefore, in this context, the procedure of scientific research is essential, in order that such social phenomena are understood so that, later, improvements in the lives of the Brazilian people can be made.

For this reason, the present research aim is to analyze the crime from the psychological perspective and, above all, from a legal perspective. Another point to be highlighted concerns the specificity of the proposed look, since such analysis is restricted to Brazil. In this axis, due to this delimitation, it is impossible to disregard the importance of this reflection, which will seek to gleam the original causes of the criminal practice, the reasons for its permanency and also its relationship with public security policies. 
Moreover,it is noteworthy that the geographic field of the research analysis is Brazil, as well as the society that composes it. In this aspect, the proportion taken by the social phenomenon of crime in the country is noticeable, such that, in the national environment, there has been a banalization of the illicit, based not only on the quantity of criminal practices, but also on the posture that the social body has adopted in relation to them. With this phenomenon in mind, it is necessary to raise questions about the origins and factors that led to its consolidation.

The problem that guides the research points to: "Why was the practice of crimes trivialized in Brazil?". In this context, the general objective sought to analyze crime in Brazil through the Legal Psychology perspective and, the specifics objectives were:

a) to study the origins of the crime practices in the country;b) to analyze impunity and its relation with the criminal practice;

c) to investigatethe effectiveness of thecontemporary crime laws in Brazil.

Then, the origins of criminal practice are described from the Legal Psychology perspective, in addition to search a relationship between impunity and the consolidation of the banalization of crime in the country. Added to this, the Brazilian State performance and its policies for crimes containment were investigated. Such effort results from the sad social involvements built in the country, which, although officially at peace, has homicide rates so high that some specialists characterize it as a country in a civil war state.

The research also reports the objective content, reflecting on the dystopian and violent reality present in Brazil and which factors have influence in the conjuncture. Thus, an attempt is made to draw attention to a banal yet problematic conjecture, raising questions about the social situation and how it deals with its surrounding conjecture, as well as how this interferes in the systematics of the crime trivialization.

Discussing the Brazilian delinquency theme is relevant due to the evolution scenario that the disorders have figured in recent decades with the time and contemporaneity progression. Despite the constant evolution of civil disobedience numbers, it is implied how the legal system is sometimes unable to keep up with sanctions and disciplinary measures to the spread and development of the country's delinquency rates, acting also, in some cases, as a contributing factor to its current proportion.

The research is characterized as bibliographical, based in the literature of Beato Filho (1999), Foucault
(1999), Cerqueira and Bueno (2020), Fiorelli and Mangini (2020), and other authors. Bibliographic research is defined as the investigation of theoretical material on the interest subject. (ALYRIO, 2011).

Literary review is structured around the individual being, criminality and society; the criminal practice genesis; the relationship between impunity and the crime practice; the crime fighting laws and their effectiveness; as well as final considerations.

\section{MAN, DELICT AND SOCIETY}

Under the sphere of humanistic studies, social relations and crime practices, the approach of Fiorelli and Mangini (2020) stands out, which presented important discussions on the subject, in order not only to present it, but also link it to a series of factors such as impunity and bad examples during the individual moral and intellectual formation period. This, added to their extensive credentials, have made them references in the Legal Psychology field, accomplishing important contributions, such as tracing the relationship between the individual and the social, as well as its effects on the legal world.

In this way, it is worth noting that such authors attribute the propensity to criminality and its relationship, among other factors, to geography, the individual's moral formation, family relationships during childhood and adolescence. Fiorelli and Mangini (2020, p. 315) say: "About the geography of crime, let us say, it is democratic. There is no social class or type of individual that is immune, preferred or predominant. The ways may vary, which adjust to social, cultural and economic limits these yes, implacable.".

Furthermore, the authors stated great emphasis on the issue of impunity capacity as a way of influencing the illicit, as Fiorelli and Mangini (2020, p. 326, author's highlight) comment:

Another factor of great significance to encourage the crime practice is the expectation of impunity (whether it is formally instituted or not), developed from the observation of reality itself. The child already perceives, through conversations and news, that people commit varied crimes and little or nothing happens to them; and this is aggravated when, in their living environment, there are individuals who brag of reprehensible acts (to say the least), despise other people and ridicule the mechanisms of social control.

Little by little, he develops the rooted belief that crime punishment does not apply to everyone and that, if certain precautions are counted, he will be able to practice them with premeditated risk. 
In this sense, it is noted that in addition to the social, the individual must also be analyzed in terms of crime production. Thus, we start from the thought of Fiorelli and Mangini (2020) as the basis for the discussions established in this research, in the desire to have a solid and structured foundation, especially in other authors works and approaches to impunity and its relationship with crime trivialization. Furthermore, studies on impunity indices present in Brazilian society are used, as well as sociological and criminological works, with the aim of achieving a broad view of the studied phenomenon.

In front of this marked axis, the book Juridical Psychology - Fiorelli and Mangini (2020) - allows a preliminary analysis of the object. In the sixth chapter of this work, the authors deal with A look at the delinquent, where they point out the delinquency genesis, trivialization as a form of perpetuation, and the relationship between crime and consequence.

Mainly, with what concerns to the original causes of criminal practice, Fiorelli and Mangini (2020) address the hypotheses regarding the factors that lead to this conduct. The hypothesis of genetic predisposition is immediately rejected, after all, there is no effective proof in this aspect. Moreover, the family dynamics and its influence in this process a potential delinquent formation is highlighted, which manifests itself:

[...] by learning inappropriate values for healthy social interaction; the child hears the parent talk about the corruption they commit, the bad check they use, the unpaid debt, and believes that these proceedings are part of the unique art of 'taking advantage of everything' [...] (FIORELLI; MANGINI , 2020, p. 317).

In this same sense, Franco (2011 apud FIORELLI; MANGINI, 2020, p. 317) understands that the "delinquency, the last stage of social breakage, is usually the epilogue of family bankruptcy." Therefore, it is clear the importance of the primary socialization process, which is the family, in the formation of the individual and, in these specific cases, the delinquent.

From another perspective, Fiorelli and Mangini (2020, p. 318) add that, in case of family omission, "[...] there will be close fiends who will take an important place as role models.". It is in this aspect that the school's interference in the individual development acts. The predominance of a model observation is perceived as a central element of the hypotheses dealt with, to the detriment of biological explanation — the delinquent's genetic predisposition thesis. Thus, it is essential, from this first theorization, initially based only on the look of Fiorelli and Mangini (2020), to investigate in which aspects this is effective, through other bibliographic references and, of course, through scientific research wellknown methods. It is in this way that the aforementioned objectives will be achieved and, thus, the gradual evolution of Brazilian delinquency will be understood.

Besides the delinquency problem explanation, a bibliographical research will be made in order to have a comprehensive explanation of each crime topic to be discussed later. As an example, when talking about the effectiveness of contemporary conflict containment systems, Foucault (1999, p. 101) says:

The criminal law reform must be read as a strategy for reallocating the power to punish, according to modalities that become more regular, more effective, more constant and better detailed in their effects; finally, that they increase the effects by decreasing the economic cost (that is, dissociating it from the ownership system, purchases and sales, from the venality of both trades and own decisions) and its political cost (disassociating it from the arbitrary power of the monarchy).

In this perspective, the legal and public spheres play crucial roles in the suppression of crimes within the Brazilian context, but they do not completely use their potential to end the criminal act. Continuing, Beato Filho (1999) speaks about the drama related to crime in Brazil, where the rulers only want to exterminate criminal acts in places inhabited by the higher-income population, placing citizens with less purchasing power at an inferior level and leaving them as the neglected ones.

\section{THE DELICTUAL PRACTICE GENESIS}

It is unquestionable that the search for a harmonious and stable coexistence has been among the pillars of society since its conception, at last, it would be impossible to conceive the idea of human coexistence without such guarantees. In contrast to this vital stipulation, populations are faced with individuals whose behavior swerves from the normative curve, putting into question any and all feelings of security and peace.

In Brazil, such dissonance is evident, as demonstrated by the Institute for Applied Economic Research (IPEA), when it has been stated by the institute that, in 2017, the country had its highest rate of homicides for every 100,000 (one hundred thousand) inhabitants in the last four decades (CERQUEIRA; BUENO, 2020). Faced with this scenario of social anomie, solutions emerge, including miraculous ones without any scientific basis, soaked with irrationality and in visible conflict with fundamental principles that underpin the democratic state, which must be vividly fought. 
Therefore, it stands out that such solutions - state actions made with the aim of mitigating criminal practices - only exist, with concreteness and efficiency, through scientific research, mainly those that aim to understand the origins of delinquency, as pointed out by Cerqueira and Lobão (2003, p. 1): "Theories of crime causes, by shedding light on certain variables and their epidemiology, allow the state planner to choose between countless variables those that virtually should be more important.". It is through this perspective that the research is carried out.

\section{The biological perspective}

Firstly, it is worth noting that there is no general theory for the criminal practice origin, after all, there is no general criminality, as each illicit act is individual and is influenced by numerous independent factors.

Inside the theoretical universe that focuses on this issue, the idea of Lombroso (2007 apud BANDEIRA; PORTUGAL, 2017, p. 31) is evident, who, based on the empirical-inductive method, understands the offender as "[...] an atavistic being, product of regression to primitive human states, a sub-man, or even species distinct from homo sapiens, as a consequence of a hereditary 'leap backward'.". Therefore, the conception of crime as a natural phenomenon, involved in a paradigm linked to the genetic issue of the offender, is notorious. This perspective, which comes from the Positive School of Criminology, also understands the transgressor as possessing certain physical, physiological and psychological characteristics degree of intelligence - which, since his birth, differentiated him from other citizens. However, it is essential to underline the evident discriminatory character of this understanding:

After World War II, such theories about the intrinsic psychological characteristics that criminals would have were abandoned, mainly due to their racist content, and new studies and experiments tried to show that there would be no distinction between criminals and non-criminals, either by degree of intelligence or other intrinsic psychological characteristic. (CERQUEIRA; LOBÃO, 2003, p. 5).

From another perspective, Fiorelli and Mangini (2020) also contest this hypothesis when realizing that, despite the debates made over time, such theory is not proven. In addition to this lack of evidence, Gomes and Molina (1997, p. 229) unhesitatingly discard the determinist hypothesis by arguing that "[...] most lawbreakers are surprisingly normal [neurotypic]".

Furthermore, facing the idea that the proportion of offenders is higher among those whose parents were also offenders, an argument that aims to substantiate the purported genetic predisposition as an incisive factor in criminal conduct, it is prudent to emphasize the understanding of Fiorelli and Mangini (2020), where there is a comprehension about the influence of the learning effect as a possibly determining variable in behavior. Therefore, such an argument would be justified not by the genotypic background of the delinquents, but by the relationship between them and their guardians, who played an essential role in their formation. In this tendency, the learning effect is understood as the acquisition of criminal guidelines and models that takes place through an evolutionary learning process, based on the observation and criminal behavior imitation from others (GOMES; MOLINA, 1997). Such imitative character of the behavior complex is also highlighted by Bandeira and Portugal (2017, p. 33):

The criminal regularly manifests as an imitator, less original than expected. In addition to characterizing the imitation laws to explain repetitive models of criminal behavior, TARDE professed the psychosocial theory of criminality. For him, social pedagogy was, from an etiological point of view, much more important than climate, heredity, disease or epilepsy in explaining crime, and for this reason it openly disagreed on the anthropological thesis of the born delinquent. And this is the meaning of his famous phrase 'Everyone is guilty except the criminal'.

Along these lines, as demonstrated, it is a wellknown and uncontroversial fact that such a biological perspective is not sustainable and may, in addition, slip from its objectives - which are to contribute to the development of effective criminal policies and ensure security to society - and culminate in the breeding of racists biases, whose paradigms are remarkably outdated. As evidenced, therefore, the theories that are based on social pedagogy - on the learning effect as the criminal behavior root- reveal themselves to be reasonable in the current context of Criminology, specifically, in the field of criminal etiology.

\section{The psychosocial perspective}

Once the purely biological theory is discarded, it is essential to go deeper into the factors that, along the lines of Fiorelli and Mangini (2020), effectively participate in the criminal practice construction, as they point out: "The social imposes itself above the strictly biological" (2020 , p. 318). Beforehand, it should be noted that it was with the american sociology from the Chicago School, in the mid-century. XX, that the Lombroso's (2007) thought critique took shape, centralizing the delinquency genesis in the environment influences and, in particular, in the newly emerged urban context, since, for the defenders of 
this idea, it is from it that the criminal practice is produced (CALHAU, 2009).

But as a background to this, it is necessary to understand the historical context. In this sense, it is evident that with the advent of modern capitalism, the industrial society rise and the division of social work, society experiences a behavioral revolution, taking the material character as a guiding conduct. Durkheim (2004 apud FORMIGA, 2011, p. 27), in this sense, exposes that "[...] the elements that make up economic activity are devoid of any moral character.". This same author considers that societies impose limits on individual goals and that these initially have a reasonable chance of being achieved. Such limits allow people to be content with their progress, although they are encouraged to seek greater progress. It is evident, however, that for such goals a logical limit is required - the awareness of what is unattainable, however, individuals are unable to conceive it and, therefore, become uncontrollable in the pursuit of their goals (DURKHEIM apud FORMIGA , 2011). It should also be remembered that those with greater resources consequently have higher goals. Therefore, this discrepancy scenario would be responsible for the state of social anomie that, due to the greed for greater results, would lead the individual to break with human values, culminating in social conflicts, such as criminal practice. In this sense, Calhau (2009, p. 67) correlates the anomic status and delinquency by stating that:

The primary groups deterioration (family etc.), the qualitative modification of interpersonal relationships that become superficial, the high mobility and the consequent loss of roots in the place of residence, the traditional and family values crisis, overpopulation, the tempting proximity to the commercial and industrial areas where wealth accumulates and the aforementioned weakening of social control create a disorganized and criminal environment.

In this fashion, criminal conduct would not be the product of biological factors, as proposed by the determinists, but rather the result of the social disturbance of the environment in which the individual is immersed.

From another prospect, but still from a psychosocial perspective, Fiorelli and Mangini (2020, p.317) point to the home as a determining element in the individual's behavior model formation, as they state that in this environment "[...] the bases of beliefs, values and fundamentals of each individual behavior are installed, which will later be reflected in positive or negative conditioning in their interpersonal relationships.". It is in the family environment that the individual, the child, will learn how to relate to the environment, especially when it comes to illegal acts (FIORELLI; MANGINI, 2020). These authors understand that criminal conduct germinates in family life, when the child hears from the parents about the corruption committed by them and starts to value such behavior positively, for example. This happens through the so-called observation of models, which is defined as "The totality of the process by which a model exposes the behavior (figuration) and the subject reproduces the behavior (imitation) [...]" (BORGES-ANDRADE, 1981, p. 4).

Beyond this, the cases of parental omission should be highlighted, in which the self-styled "affective outsourcing" occurs, in which children and adolescents resort to other social structures, such as the school. The the school environment's importance is enormous, aggravated even in the absence of parents, as highlighted by Fiorelli and Mangini (2020, p. 318): "If parents are silent or absent, there will be closer companions who will conquer an important place as role models. ". It is at school that the child comes into contact with the different and, in the fragility of primary socialization - which occurs at home, it is the relationships developed in the school environment that will forge the central pivot of the individual's behavior, making him vulnerable, therefore, because it is not possible to ensure that this pivot is in line with the society's normative order.

Consequently, it becomes evident that delinquency has its origin marked by an imbalanced state in the systems that aim to guarantee social cohesion order, whether in the moral, religious and, in the latter case, family aspect. In addition, once the criminal practice originates and, as the other regulatory complexes are insufficient to guarantee a harmonious coexistence, the punitive power of the State is ultimately resorted to, which, among several problems, is still seen as ineffective, generating a feeling of impunity in part of the population, which, in turn, does not foresee a safe and stable horizon for human coexistence.

\section{RELATION BETWEEN IMPUNITY AND CRIME PRACTICE}

In this analysis context of the Brazilian social spectrum, it is necessary to point out a factor of accentuated relevance in the criminal practice scope: impunity. In this perspective, although it has a broad and structured judicial and police system, the Brazilian State has not been able to bring practical effectiveness to such a system. This can be seen in Nery and Nadanovski (2020), who determined that, in the period between 2009 and 2014, alone, there were more than 240 thousand cases of homicides, whose suspects were not identified or arrested. This situation is also more recently demonstrated in Bueno 
and Lima (2019), who admit and prove the high rate of impunity, especially in relation to violent crimes, in Brazil. Added to this, media cases of impunity for corruption crimes reinforce the popular notion of impunity in the country, which contributes to the development of a culture that is not fearful of the regulatory system and discredited with regard to the justice promotion by the State.

Still according to the national scene, the situation is so aggravating that certain scholars already point to it not as a momentary panorama, but as a cultural phenomenon, founded on the Portuguese colonial heritage, if perpetuated after the proclamation of the republic and entered into the brazilian political scene. Thus, as culture is intertwined with the social, distinct harmful phenomenologies would be derived from it, such as the non-differentiation of public and private, pointed out by Holanda (2004, p. 145-146):

It was not easy [...] to understand the fundamental distinction between the private and the public domains. [...] For the 'patrimonial' employee, the political policy presents itself as a matter of private interest; the functions, jobs and the benefits he receives from them are related to the employee's personal rights and not to objective interests, as happens in the real one. A bureaucratic state, in which the specialization of functions and the effort to guarantee legal guarantees to citizens prevail? The choice of men who will exercise public functions is made in accordance with the personal confidence that the candidates deserve, and much less in accordance with their own functions. Everything lacks the impersonal ordering that characterizes life in the bureaucratic state.

This phenomenon can also be analyzed in the light of the thought of Fiorelli and Mangini (2020), who attributed to the impunity expectation, arising from the analysis of what is real, a stimulus to the crime practice. In this sense, according to the authors, children who find themselves in an environment in which people boast about reprehensible acts committed, which did not generate punitive consequences, tend to acquire a universalizing mentality, so that they also feel that they will not be punished. Still in this context, the media romanticization of criminal acts should be condemned, as this would favor the expansion of a problematic and possibly criminal behavior model.

Withal, it is also worth pointing out that Fiorelli and Mangini (2020) establish that the use of sanctions and punishments must be weighed in each case, in view of the objective social reality. This is due, among other factors, to the Brazilian prison reality, which does not present itself adequately to resocialization, proving itself, in practice, to be an institution not endowed with equity, as social class determines, in many of the cases, the type of treatment processed by the detainee. Thus, it is essential to note that reality and practice should not be ignored in analyzes regarding the social status, that because, if this occurs, distortions present in the theoretical model will be even more evident.

Starting with a spectrum of analysis in the normative conjecture of the impunity consequences, it appears that it not only entails a trust loss by society in the legal system, but also causes doubts about its validity, efficiency and applicability. Thus, in this leaning, there is the comment of Foucault (2013, p. 92):

And above all that no crime committed escapes the gaze of those who have to do justice; nothing makes the instrument of laws more fragile than the impunity hope; How could a close link between a crime and a penalty be established in the courts minds if a certain improbability coefficient were to affect it?

In addition, in this same discussion, it is valid to point out Porto's thinking (2001, p. 338), which based on the impunity thought as opposed to reciprocity, delimits important social losses arising from this issue:

[...] impunity breaks this reciprocity chain in several ways: by minimizing the submission value to norms that are guided solely by their validity belief, by introducing selectivity in the justice administration for certain offenders and certain transgressions; by expanding the insecurity feeling, by not allowing to foresee when, under what conditions and directed to whom the legal and empirical mechanisms of social regulation and order maintenance will be activated, or when, once activated, they will act effectively; when and by whom they will be cheated and when, on the contrary, they will be put into practice with rigor, precision and efficiency [...]

In this sense, it is noteworthy that impunity not only makes the individual analyze the risk relationship for the action as favorable to the crime, but also weakens the legal system as a whole, to the extent that society itself discredits it. With this, in view of the interrelationship between the three main components of the standard (REALE, 2020), it is noted that an aggression to the system tends to provoke not only questions about the validity, but also losses on the standard social effectiveness. Thus, among these factors, it can also be listed that the Law would not be serving the common good, which, according to Reale (2020) is the legal order and science duty.

Thusly, it is noted that, in addition to a social and cultural issue, non-punishment and consequent injustices come into conflict with the legal system greater objectives, in a way that contradicts fundamental principles of law. A 
clear example is a violation of the isonomy principle, guaranteed in fifth article of the Brazilian federal constitution (BRASIL, 1988), which ensures that all citizens will be treated equally under the law, which, however, does not occur in practice, generating injustice and impunity. With this, the need for greater impetus not only in the causes study of such a phenomenon is remarkable, but also in raising solutions, in the eagerness to reduce this dilemma.

Along these lines, starting from a broad view of this situation, the various negative consequences arising from the impunity scenario are remarkable, since they permeate not only the individual psychological, but also the cultural in order to influence the legal. However, among the so-called human sciences, multiple study perspectives must be adopted. Thus, in order to make a better parameter, it is also necessary to analyze the State's posture and its policies in relation to such vice in the national situation, in order to point out the main flaws and distortions not corrected and expanded by the Brazilian State, in addition to understanding state actions on the subject.

\section{CRIME-COMBATING POLICIES AND THEIR EFFECTIVENESS}

In principle, criminal practices are seen by authorities around the world as illegal acts, prohibited by the damage they cause to society. Similarly, Brazil is no exception, seeking over time to reduce offenses through containment measures; however, most of these adopted policies urgently need improvements, which are not always adhered to by the institutions responsible for this fight. Thus, some alternatives adhered to by the Brazilian authorities are explained, verifying their real effectiveness in the country in the context of Legal Psychology.

In this tendency, the current brazilian criminal code entered into force in 1940, undergoing reforms over the years to adapt to society, which is constantly changing (BRASIL, 2017). However, it is clear that there are certain contradictions within this set of laws with the sociocultural environment of the 21 st century. In the matter of mental health, for example, certain citizens who have committed crimes but have mental disorders are framed in a sad vision of dangerousness, as Marchewka (2001, p. 111) says:

As can be seen, in Brazilian courts the positive school thought of the 19th century is still taken into account. In Brazil, despite ourcriminal codereforms, the application of a security measure, both admission to a custodial hospital and psychiatric treatment and outpatient treatment, presupposes, in addition to the typical fact, dangerousness, that is, that the agent may commit another crime.

Furthermore, the security measures adopted by Brazilian institutions do not imply ending the crime problem, but rather immediately detaining individuals who carry out these acts, that is, without giving due value to the important process of criminal rehabilitation, which takes a relatively long time. To emphasize, Foucault (1999) becomes relevant in this context when talking about punishment through security measures; this, as a way to both punish the person for the illegal act and also to "control" the individual, changing their criminal mentality. Following this thought, Brazilian policies should act in a way that punishes and re-socializes prisoners, a fact not observed in practice within the nation's territory.

Accordingly, the most famous conflict containment measure at a national level deserves attention: the penitentiaries. In these institutions there are also rules, as Gutierrez and Almeida (2008, not paginated) remind us: "[...] the rules valued in prison are built in the world of life, as reclusion is the palpable norms manifestation legitimized by a collective.". These places were created with the objective of covering the entire contingent of detainees in Brazil, where - in theory - the prisoners would return to society as citizens with no intention of carrying out any more crimes. However, many of those responsible for the administration of these prison systems (which can be both public and private) in the Brazilian states do not know how to deal with the high demand for cells, leading to overcrowding, which consequently causes the failure of the main objective of the prison complexes. , said earlier.

Thus, Adorno and Salla (2007, not paged) emphasize:

Prisons in Brazil, except for brief moments in their history, have always presented deteriorated living conditions with overcrowding, material deprivation, violence and arbitrariness. The innovations introduced in penal codes (for example, in 1890 and 1940) in terms of the sentence execution, and which could reverse those scenarios, were only very limitedly put into practice.

For a measure to contain criminal practices to be fully effective, a harmonious relationship is needed between it and the urban environment, which is a region with a high crimes concentration. Unfortunately, most Brazilian cities were not planned with an adequate infrastructure to have a gradual evolution of security along with the growth of municipalities, making the urban environment a place of intense illegal activity and irregular public security. As a result, much of the combat policies 
prove ineffective against the enormous crimes in cities proliferation, spreading widespread fear among ordinary citizens.

At this juncture, questions are being raised about the municipalities role in adopting projects to combat criminal acts within their territorial limits, something considered to be the states role alone. This is due to the fact that public safety is often neglected to the detriment of other policies considered more necessary, as Tenório Filho and Lima (2018, p. 374) present:

The lack of coherence between other public policies and public security policy makes it difficult to take action to reduce urban violence. Since there is no consensus on the actual policy to be adopted, public security spaces are left unattended, as if they were autonomous units forgotten or denied in the municipalities.

In Brazil, the social and economic inequality phenomenon also greatly influences the effectiveness and adoption of security measures. While neighborhoods of higher-income residents have a great protection apparatus, the peripheries are exposed to every possible crime type, with a selective effectiveness from protective policies. With this, one can see the forgetfulness of the democratic aspect of Brazilian justice, caused by public bodies that should be responsible for the fight against delinquency. Thus, Beato Filho (1999) adds by presenting the information that having more police officers, as in the United States and Brazil, guarantees a feeling of greater tranquility for citizens, but it does not mean a decrease in crime in these nations, where the offense rates are quite high.

Continuing, it is important to remember the rigid character of brazilian justice, which sometimes literally follows what is written in the legal system, without making a compromise with the convict's psychological aspect, that is, leaving Legal Psychology in the background. But how can this be observed? Well then, a simple way to confirm this is something pervaded in the country: violence. Offenses are often punished through violent policies against offenders, a fact that adds nothing to the psychology work. Therefore, Fiorelli and Mangini (2020, p. 385) are relevant when they say: "[...] strategies are sought to implement non-violent behavior, for a peace culture.".

Finally, it is possible to observe how the government continues incessantly looking for new solutions to end the great crime wave in the Brazilian territory, but failing to adopt poorly structured policies, which implies a legal and social ineffectiveness of these measures, which are of enormous relevance to the brazilian current context. In addition, in the Legal Psychology light, the public safety marginalization as is happening in the country cannot be allowed, because - according to Fiorelli and Mangini (2020) - it is as if delinquency belonged to people's daily lives, that is, it occurred to crime trivialization within the nation.

\section{FINAL CONSIDERATIONS}

Researching about delinquency and impunity from the Legal Psychology perspective is a relevant topic due to the need to analyze the public policies adopted in the country and their real effectiveness, proposing questions about the Brazilian criminal scenario and what factors led to the current situation.

Thus, it should be noted that the research was built based on this relevant theme, which is very current in the Brazilian context, bringing as its main issue an illicit action very common in the country: crime. Furthermore, the importance is also due to the urgent need to seek ways to reduce the number of delinquents and, consequently, enable actions to reverse the spread of delinquency that surfaced in Brazil by addressing its emergence and how it has taken on large proportions today.

The issue of delinquency comprised the central question in this research: "Why was the practice of crimes trivialized in Brazil?". The general objective aimed to analyze crime in Brazil through the Legal Psychology perspective and the specific objectives were :

a) to study the origins of the crime practices in the country;

b) to analyze impunity and its relation with the criminal practice;

c) to investigate the effectiveness of the contemporary crime laws in Brazil.

The results showed the various compositional features of the criminal situation in Brazil, passing through its genesis and formation through macro and micro social factors, its relevance and direct relationship with the justice system due to its inappropriate tools to solve any problems in the criminal scenario that the country presents.

From the bibliographical research, it was found that the criminal practice genesis does not come from a biological factor, but from a series of psychosocial factors and characteristics, present in the environment in which the individual lives and that shapes him in its various facets. Faced with a deficiency of social, family, religious or educational factors, whose presupposition would be the practice of an efficient insertion of basic moral values in the individual and collective conscience of that citizen, the psychosocially marginalized individual is therefore in a 
potential for imbalance of their mental faculties and, consequently, for the criminal practice exercise.

It is also inferred that the impunity persistence assertively contributes to the criminal practice permanence in Brazilian society, and that in some cases, the legal system is unable even to identify criminals, thus making it impossible to apply disciplinary measures, as proven in the statistical data presented in the course of the article. Therefore, the direct relationship that impunity has to the criminal rate aggregation is accentuated over the decades become indisputable. Therefore, the direct relationship that impunity has to the criminal rate aggregation so accentuated over the decades becomes indisputable.

The ineffectiveness that the judiciary system presents in relation to its own meaning is also an aggravating factor, since the prison system has in its purpose the individual resocialization and their adaptation to a new social life reformulated during their stay in the prison system, as noted in the Fiorelli and Mangini (2020) literature. Finally, it is suggested the application of policies that modify the prison system, so that it works in an objectively efficient way with regard to the delinquents containment and its reformulation for a later insertion in society in a dignified manner. Parallel to this, it is necessary to increase awareness about the psychosocial development importance as different life stages have for the full establishment of each individual's psychological faculties and the adoption of efficient palliative measures if deficiencies are found in the institutions.

\section{REFERENCES}

[1] ADORNO, S.; SALLA, F. Criminalidade organizada nas prisões e os ataques do PCC. Estudos Avançados, São Paulo, v. 21, n. 61, 2007. Disponível em: https://www.scielo.br/j/ea/a/mWPVHtSNcZYQjCxPtvMRr Dx/?lang=pt\#. Acesso em: 18 ago. 2021.

[2] ALYRIO, R. D. Métodos e técnicas de pesquisa em administração. Rio de Janeiro: Fundação CECIERJ, 2009.

[3] BANDEIRA, T.; PORTUGAL, D. As origens do saber criminológico. In: BANDEIRA, T.; PORTUGAL, D. Criminologia. Salvador: UFBA, 2017. cap. 2, p. 27-36. Disponível

em: https://educapes.capes.gov.br/bitstream/capes/174993/4/eBo ok_Criminologia-

Tecnologia_em_Seguranca_Publica_UFBA.pdf. Acesso em: 20 ago. 2021.

[4] BEATO FILHO, C. C. Políticas públicas de segurança e a questão policial. São Paulo em Perspectiva, São Paulo, v. 13, n. 4, dez. 1999. Disponível em: https://www.scielo.br/j/spp/a/dkVcT4srWc8d6MS6yRvbLPt /?format=html\&lang=pt. Acesso em: 10 ago. 2021.

[5] BORGES-ANDRADE, J. E. Aprendizagem por observação: perspectivas teóricas e contribuições para o planejamento instrucional - uma revisão. Psicol. cienc. prof., Brasília, DF, v. 1, n. 2, p. 2-68, jul. 1981. Disponível em: pepsic.bvsalud.org/pdf/pcp/v1n2/01.pdf. Acesso em: 23 ago. 2021.

[6] BRASIL. Código penal. Brasília, DF: Senado Federal, 2017. Disponível

em: https://www2.senado.leg.br/bdsf/bitstream/handle/id/529748 /codigo_penal_1ed.pdf. Acesso em: 25 ago. 2021.

[7] BRASIL. [Constituição (1988)]. Constituição da República Federativa do Brasil de 1988. Brasília, DF: Presidência da República, $1988 . \quad$ Disponível em: http://www.planalto.gov.br/ccivil_03/constituicao/constituic ao.htm. Acesso em: 19 ago. 2021.

[8] CALHAU, L. B. Teorias macrossociológicas da criminalidade. In: CALHAU, L. B. Resumo de criminologia. 4. ed. Rio de Janeiro: Impetus, 2009. cap. 8, p. 63-88. Disponível em: http://arquimedes.adv.br/livros100/Resumo de Criminologia-Lélio Braga Calhau.pdf. Acesso em: 22 ago. 2021.

[9] CERQUEIRA, D. 13 razões porque. In: ANUÁRIO brasileiro de segurança pública. São Paulo: Fórum Brasileiro de Segurança Pública, 2019. p. 168-171. Disponível em: https://www.forumseguranca.org.br/wpcontent/uploads/2019/10/Anuario-2019FINAL_21.10.19.pdf. Acesso em: 18 ago. 2021.

[10] CERQUEIRA, D. R. de C.; BUENO, S. (coord.). Conjuntura da violência letal no Brasil. In: CERQUEIRA, D. R. de C.; BUENO, S. (coord.). Atlas da violência 2020. Brasília, DF: Ministério da Economia: IPEA, 2020. cap 1, p. 7-13. Disponível em: http://repositorio.ipea.gov.br/handle/11058/10214. Acesso em: 19 ago. 2021.

[11] CERQUEIRA, D.; LOBÃO, W. Determinantes da criminalidade: uma resenha dos modelos teóricos e resultados empíricos. Brasília, DF: Ministério da Economia: IPEA, 2003.

[12] FIORELLI, J. O.; MANGINI, R. C. R. Um olhar sobre o delinquente. In: FIORELLI, J. O.; MANGINI, R. C. R. Psicologia Jurídica. 10. ed. rev. atual. São Paulo: Atlas, 2020. cap. 6, p. 305-356. Disponível em: https://forumturbo.org/wpcontent/uploads/wpforo/attachments/43833/3566Psicologia-Juridica-Jos-Osmir-Fiorelli-e-Rosana-CathyaRagazzoni-Mangini-2020.pdf. Acesso em: 19 ago. 2021.

[13] FOUCAULT, M. A punição generalizada. In: FOUCAULT, M. Vigiar e punir. 41. ed. Petrópolis: Vozes, 2013. p. 71-99.

[14] FOUCAULT, M. Vigiar e punir: nascimento da prisão. 20. ed. Petrópolis: Vozes, 1999. p. 22. Disponível em: https://www.ufsj.edu.br/portal2repositorio/File/centrocultural/foucault_vigiar_punir.pdf. Acesso em: 9 ago. 2021.

[15] FORMIGA, N. S. Anomia: teoria e pesquisa. In: FORMIGA, N. S. Moralidade, anomia social e condutas antissociais e delitivas de jovens de diferentes contextos sócioeducacionais: verificação de um modelo teórico. 2011. Tese (Doutorado em Psicologia Social) - Programa de PósGraduação em Psicologia, Universidade Federal da Paraíba, João Pessoa, 2011. f. 18-45. 
[16] GOMES, L. F.; MOLINA, A. G. P. Criminologia. 2. ed. São Paulo: Revista dos Tribunais, 1997.

[17] GUTIERREZ, G.; ALMEIDA, M. B. de. Cultura e lazer: uma aproximação habermasiana. Lua Nova, São Paulo, n. 74, 2008. Disponível em: https://www.scielo.br/j/ln/a/pnX8yzqgKd4BjQ7GR9V4xzb/ ?lang=pt\#. Acesso em: 20 ago. 2021.

[18] HOLANDA, S. B. de. O homem cordial. In: HOLANDA, S. B. de. Raízes do Brasil. 26. ed. São Paulo: Companhia das Letras, 2004. cap. 5, p. 139-152. Disponível em:

[19] http://www.unirio.br/unirio/unirio/cchs/ess/Members/debora .holanda/teorias-do-brasil-2019-01/unidade-2/raizes-dobrasil-sergio-buarque-de-holanda/at_download/file. Acesso em: 19 ago. 2021.

[20] LOMBROSO, C. O homem delinquente. Tradução de Sebastião José Roque. São Paulo: Ícone, 2007. (Coleção Fundamentos do Direito).

[21] MARCHEWKA, T. M. N. As contradições das medidas de segurança no contexto do direito penal e da reforma psiquiátrica no Brasil. Revista de Direito Sanitário, [s. 1.], v. 2, n. 3, p. 102-111, 2001. DOI: 10.11606/issn.23169044.v2i3p102-111. Disponível em: https://www.revistas.usp.br/rdisan/article/view/82762. Acesso em: 18 ago. 2021.

[22] NERY, F. S.; NADANOVSKY, P. A impunidade do homicídio no Brasil entre 2006 e 2016. Revista de Saúde Pública, São Paulo, n. 54, p. 7, 2020. Disponível em: https://www.scielo.br/j/rsp/a/jqfYgrkTf53rFkHq9jCsPHN/?f ormat=pdf\&lang=pt. Acesso em: 18 ago. 2021.

[23] PORTO, M. S. G. Impunidade: avesso da reciprocidade. In: CONGRESSO DA SOCIEDADE BRASILEIRA DE SOCIOLOGIA, 10., 3-6 set. 2001, Fortaleza. Anais eletrônicos [...]. Brasília, DF: Sociedade Brasileira de Sociologia, 2001. Disponível em: https://www.scielo.br/j/se/a/YBzWNxHLswMxB6Rrft5qgS P/?format=pdf\&lang=pt. Acesso em: 19 ago. 2021.

[24] REALE, M. Conceito de Direito: sua estrutura tridimensional. In: REALE, M. Lições preliminares de Direito. São Paulo: Saraiva, 2002. cap. 6, p. 59-68.

[25] TENÓRIO FILHO, J. R.; LIMA, S. F. C. de. Construções penais e o diálogo com a cidade: a (não) política de implantação de equipamentos penais no meio urbano. urbe. Revista Brasileira de Gestão Urbana, Curitiba, v. 10, n. 2, p. 371-386, maio/ago. 2018. Disponível em: https://www.scielo.br/j/urbe/a/gGv6ZcQxgd47LCtftqtdhMz/ ?lang=pt\#. Acesso em: 19 ago. 2021. 